\title{
工作機械とロボットを完全融合した ロボット内蔵工作機械の開発* \\ Development of a Fully Integrated Machine Tool with Built-In Robot
}

\section{森村章一** 杉浦弘幸** 井口憲二** 吉村辰浩** 柴田知宏**}

Shoichi MORIMURA, Hiroyuki SUGIURA, Kenji IGUCHI, Tatsuhiro YOSHIMURA and Tomohiro SHIBATA

\section{1. は じめに}

先進国においては，本格的な人口減少社会に突入してい る。 日本では, 団塊の世代が 70 歳以上に達し, さらに少 子化も加わり, 労働人口の急速な減少が予想されている. 製造現場も例外ではなく，人材確保が大きな課題となって おり，特に中小企業の労働力不足が深刻である.

そのような背景から, 中小企業においても, ロボットな どを用いた自動化技術が重要となってきているが，ロボッ トの導入実績は非常に少ない. このことについての特に大 きな課題として，下記のようなものが挙げられる.

・ロボットを扱う専門の知識や技術が必要であり，製造 現場の作業者（工作機械のオペレータ）が扱うには, ロボット操作が難し過ぎること

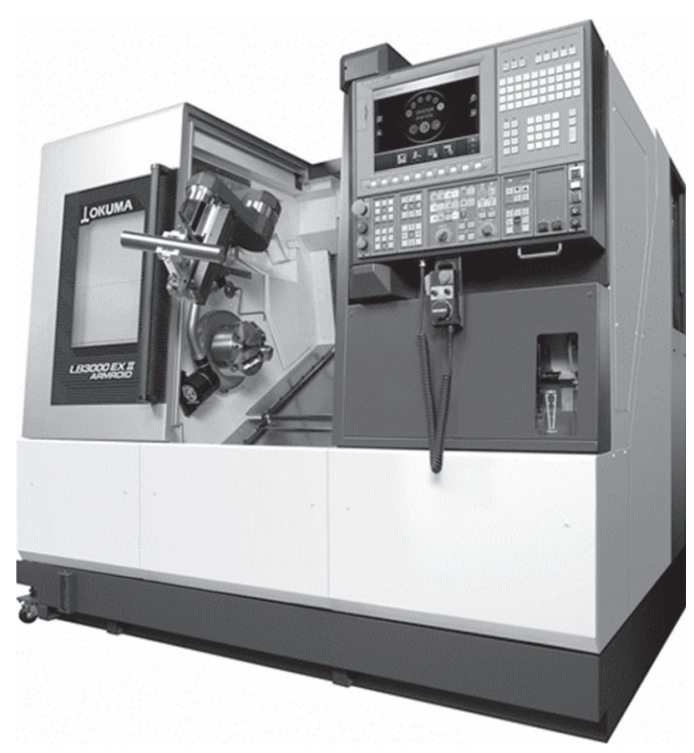

図 1 開発したロボット内蔵工作機械の外観
・ロボットと作業者との親和性が低く生産の柔軟性が低 下し, 変種変量生産に向かないこと（ロボットを設置 すると，ロボットがじゃまで作業者が作業できないこ と)

・ロボットを覆う安全柵が必要となり, 自動化専用の広 いスペースが必要であること

・ロボットをワーク搬送にしか用いないとすると, 費用 対効果が高くないこと

これらの課題は, 工作機械の思想とロボットの思想が必 ずしも合っておらず，両者にずれが生じたためと考えられ る.これらの課題を解決すべく, 本開発ではコンパクトな $\mathrm{CNC}$ 旋盤とロボットを完全融合したロボット内蔵工作機 械を開発した (図 1 $)^{122)}$ 。ロボットを内蔵した効果を十分 に発揮するために，工作機械への融合を前提とした専用口 ボットを開発し, 制御系・操作系についても工作機械と一 体となったものを開発した。これらの融合開発について は, 第 2 章で説明する。 また, 開発した工作機械では, 従 来のワーク搬送だけの使い方 ${ }^{3}$ にとどまらず，加工のサポ ートをすることも可能とした。ここれらの使用事例につい て，第 3 章で説明する。

\section{2. 工作機械とロボットの融合開発}

本開発では, コンパクトな横形の CNC 旋盤を対象と し，ロボットとの融合開発を行った。この理由としては, ・中小企業を含め, 数多くの製造現場で使用されるス夕 ンダードなタイプの工作機械であること

・それにもかかわらず，旋削加工時の切粉が絡まったり 堆積したりするなど自動化の阻害要因が多いこと などが挙げられ，これらを解決したときの波及効果が非常 に大きいと考えられたためである。

ロボットを CNC 旋盤の限られた機内空間に配置する 際, 加工サポートをするなどロボットの導入効果を高める ためには，以下が必須であると考えられる。

・加工中も含め, ロボットが機内を自由に動けること

・ロボットが旋盤本来の機能を阻害せず共存できること

・ワークを扱えるだけの可搬重量を有すること

*原稿受付 令和元年 11 月 8 日
*オークマ(株) (愛知県丹羽郡大口町下小口 5-25-1) 


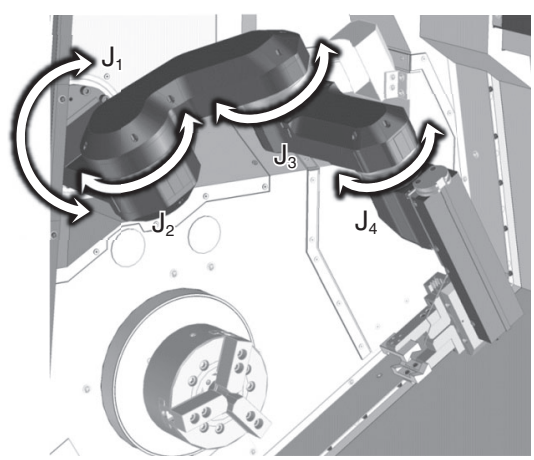

(a) 軸構成

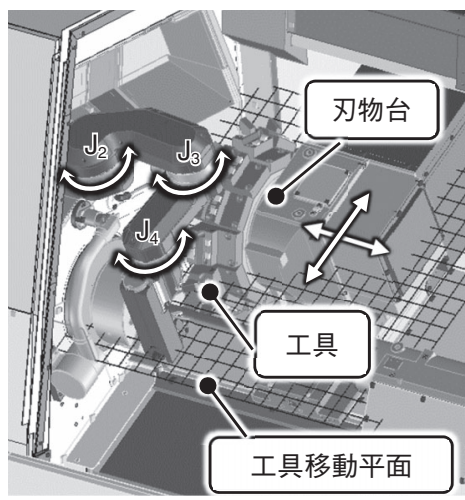

（b）加エサポート時の動作範囲

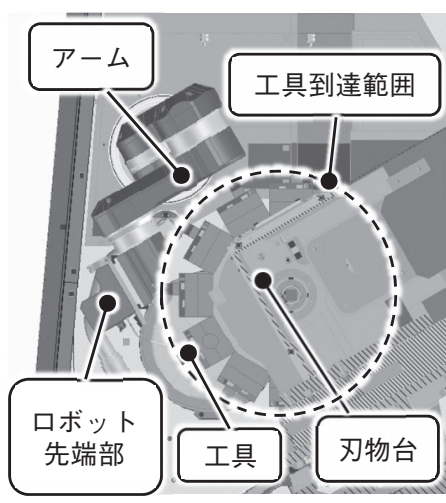

（c）アームとの干渉回避

図 2 開発したロボットの構造（※ $\mathrm{J}_{n}=$ 第 $n$ 関節 $)$

・切粉や切削水などの悪環境にも耐えられること

・(コンパクトな) CNC 旋盤に釣り合う安価なロボット であること

しかしながら, 沉用的な産業用ロボットでは, これらを同 時に満たすことができない，一方で，工作機械の機内とい う決まった空間であり，必ずしも汎用的な産業用ロボット のようなどのような動きも行えるといったことも必要な く, 機内で必要な動作のみ行えればよい.このことから, $\mathrm{CNC}$ 旋盤に内蔵することを前提としたロボット構造を考 案し開発した（図2）。

このロボットの制御軸数 (自由度, 関節数) は 4 とあえ て少ないものとしている（図 $2(\mathrm{a})$ ). 制御軸数を必要最 小限とすることで，狭い機内にロボットを収めつつ，モー 夕や減速機を可能な限り大きくして, 可搬重量や剛性を確 保するのが狙いである。また，制御軸数が少なくなること で, 減速機, モータ, アンプなどの必要数が減るため安価 になる. CNC 旋盤では, ワークを回転させた状態で, 刃 物台や工具をワークの長手方向と径方向の 2 方向にのみ移 動させ加工を行う．このような加工の最中に加工サポート を行うことを考えると, 加工点に追従させ切削水をかける にしても，ワークのびびりを抑えるためにワークを支える にしても，工具の移動平面内で 2 方向の並進移動と 1 方向 の回転移動（姿勢変更）ができれば，多くの作業が行える (図 2 (b) ). 3 軸スカラロボットが水平面内で動作するの と同様に，このロボットは工具の移動する傾斜面内（もし くはその面に平行な傾斜面内）で移動し加工サポートを行 うことができる。このロボットは, ワークを搬送する際に 機外にロボットの手先が届くように, ロボットの根本の位 置をドア寄りにしている。そのため, 加工中のドアが閉ま った状態では，機内側にアームを折りたたんで使用する. この際, 刃物台はロボットに接近してくるため, ロボット と刃物台の干渉を考慮する必要がある。そこで, 刃物台お よび工具が到達する範囲を考慮し，アームが工具到達範囲 より斜め上方にくるように設置し, アームと刃物台や工具 が干渉しないものとした（図 2 (c)). なお,この箇所は, 刃物台が斜めに移動する CNC 旋盤においてデッドスペー
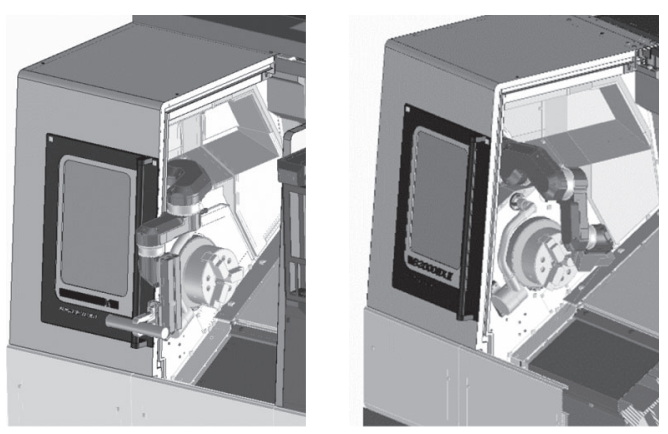

図 3 機械加工中以外のロボット動作

スになりやすい箇所であり，そこを有効に利用している. これにより，工作機械がもつ刃物台の移動ストロークを制 限することなく，干渉しないようにロボットが動作可能で ある。

加工中の加工サポート以外の作業, 例えば機外とのワー クの受け渡しや機内の切粉清掃等では, 根本の回転軸を用 いることで, 水平方向に機外へのワークの受け渡し, 鉛直 方向の機内清掃なども行えるようになっている（図3）.

ほかにも, ロボットの動作が工作機械の加工に影響を与 えないように振動絶縁をする, ロボットが切粉や切削水に 耐えられる構造とするなど必要な項目は多くあるが, それ らの説明はここでは割愛する。

本開発においては, 工作機械とロボットは電気的にも融 合を図っている。その目的としては，以下が挙げられる。

·工作機械の動作（刃物台の送り動作など）とロボット の動作の同時動作により, 加工中のロボットによる加 工サポートを可能とするため

・工作機械の作業者が, ロボットを簡単に扱えるように するため

図 4 は, 操作画面の一例であり, 対話画面により簡単 なパラメータのみ入力することで, ロボットが動作を自動 で決定するとともに，刃物台などの動作に合わせて同時動 作することも可能となっている. 刃物台などとロボットが 統合されたシミュレーションにより，動作も確認できるも 


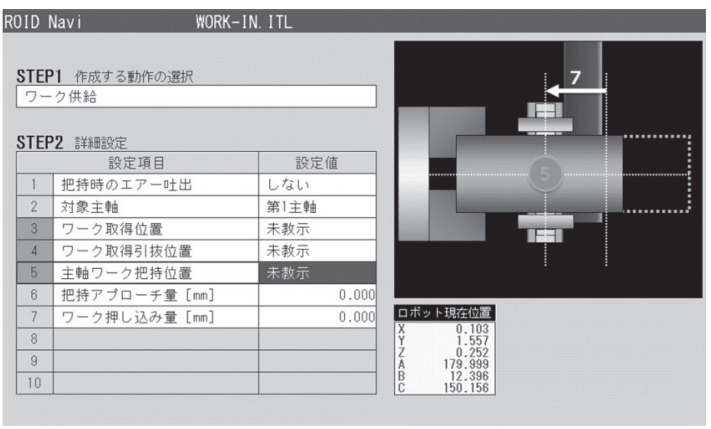

図 4 ロボット操作画面

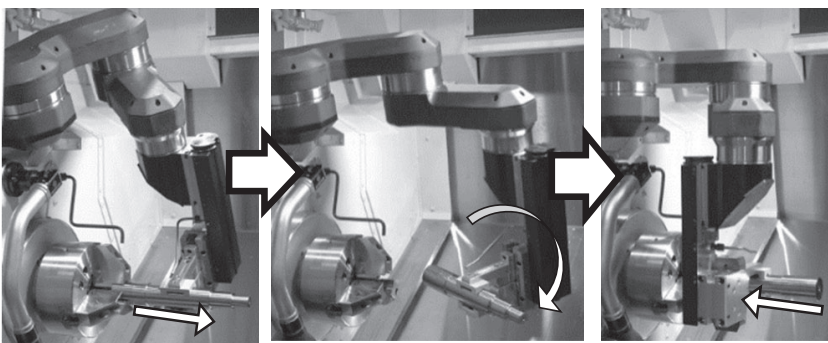

図 5 ワーク反転

のとした．これによって，次章に示すような加工サポート も可能となった

\section{3. 実験と使用事例}

開発したロボット内蔵工作機械による作業内容としては さまざまなものが考えられるが，一部の使用事例と実験結 果を以下に述べる.

一般的な工作機械の機外に設置されたロボットシステム において，最も重要な作業はワークの交換作業である。本 開発の最も大きな特徵は機内で加工サポートができること であるが，一般的なロボットと同様にワークの交換作業や 反転作業なども可能である（図 5)。また，機外に設置さ れたワークストッカへのアクセスも十分に可能である.

また，機内（ドアの内側）にロボットがあるため，切削 水やエアなどの流体を任意の箇所に任意の方向から自在に 噴射することができる（図 6)。これにより，

・チャック，工具，ワークなどに付着した切粉を清掃し

加工の品質を安定させること

・エアを用いて付着した切削水を吹き飛ばしてから，ワ

ークを払い出すこと

・可動部などに切粉が挟まることを防止し, 故障やチョ コ停などのトラブルを未然に防ぐこと

・ワークの材質が変更されるときに，機内の切粉を完全 に取り去ってから次の加工に進むこと（※材質の異な る切粉が混ざると、リサイクルの観点から問題) などができる。なお，これらのことは，従来は基本的に人 手により行っており，無人運転の妨げとなっていた。さら には，加工サポートにも用いることができる，刃物台との

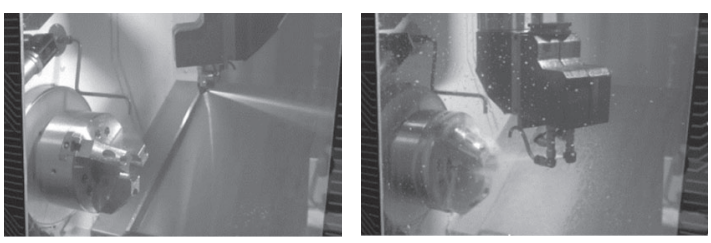

図 6 機内清掃

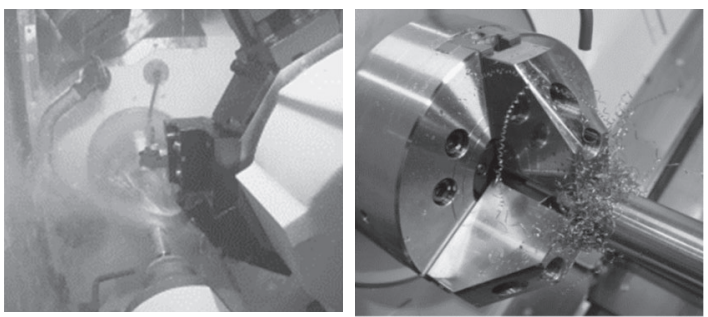

(a) 切粉誘導なし

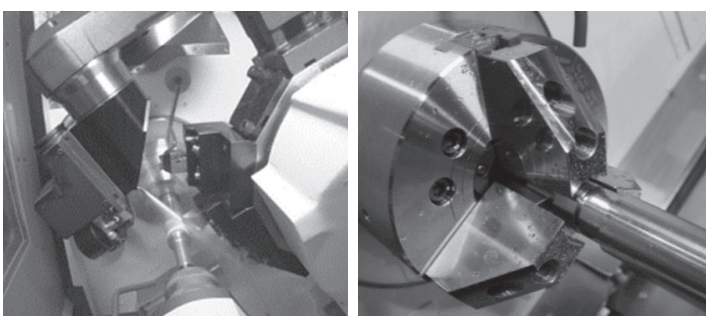

(a) 切粉誘導あり

図 7 切粉誘導の効果

干渉を避けながら, 加工点で発生する切粉にピンポイント で切削水を噴射することで，連続型の切粉の流れる方向を 制御し，ワークや工具への絡まりを防止することが可能と なる。図 7 はその実験の様子であり, 同一条件の旋削加 工においてロボットによる切粉誘導の有無で比較をしたも のであるが，切粉誘導によって切粉の絡まりが抑制されて いることが分かる．固定ノズルでは不可能であった加工中 の噴射方向変更も容易であり，ワークの形状に合わせて噴 射位置を変更できる。なお，この実験においては，流体の 力をより強力にするため, 切削水とエアを混合したミキシ ングブローを使用している.

また，ワークのびびり抑制に用いることも可能である. ワークのびびりを抑えるためには，加工条件で対応するこ とも多いが，それは常に可能なわけではない。そのような 場合には，一般的には振れ止め装置を用いるが，必要がな いときにはじゃまであり変種変量生産には適さない。能動 の振れ止め機構 ${ }^{4)}$ 提案されており，このようなことをロ ボットで行えれば, ワークのびびりを防止でき，必要ない ときには邪魔にならないものとできる。図８は，ロボッ トの先端にローラを取り付けワークを支えるワークサポー トの効果を確かめたものである。この図より、ワークサポ ートによって，ワーク表面の縞目がなくなり，びびりが抑 制されていることが確認できる。なお，ローラにはばねが 仕込まれており，押し付け量を調整して支持力をコントロ 


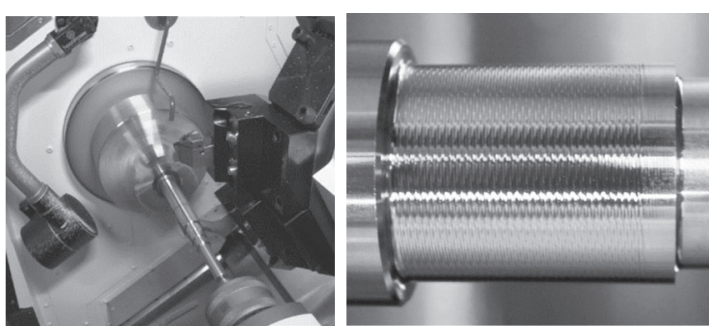

(a) ワークサポートなし

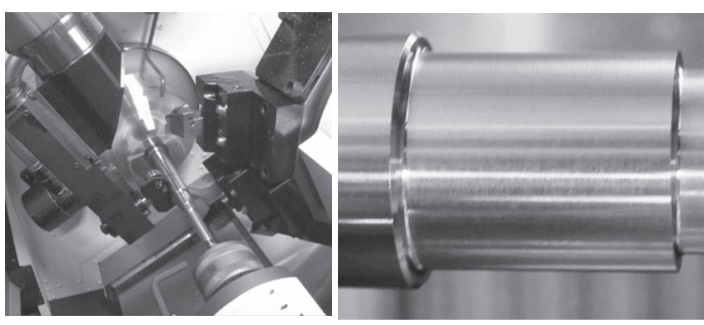

(b) ワークサポートあり

図 8 ワークサポートの効果

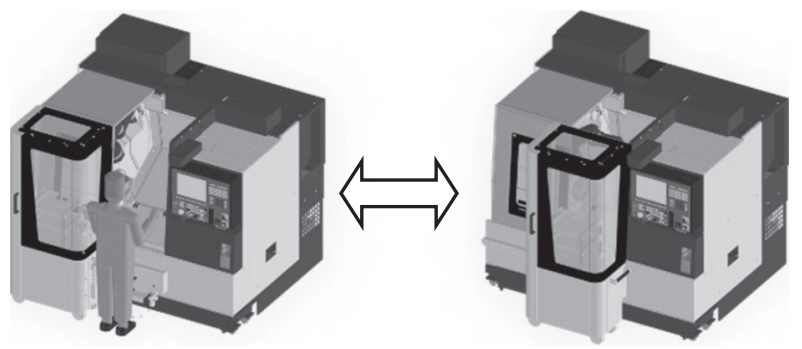

図 9 運用の切り替えの一例

ールできるものとして実験している。この方法は, ロボッ トで行うため, ワークの段差・ワークの交換・加工の進行 に対応して支持部の直径を変更すること, ワークの形状に よって支える方向（ラジアル方向だけでなく，アキシャル 方向や傾斜した方向）を切り替えること，これらを即座に 行うことができる。

工作機械の使い方として, 必ずしも常に完全自動化が求 められているとは限らず, 作業者が手扱いで加工を行いた い場合もある. 特に, 小ロット部品では, 自動運転のプロ グラムを作成するよりも，作業者が手扱いで加工する方が 早い場合も多くある。このような使い方と, ロボットを利 用する使い方を簡単に切り替えできないと, 変種変量生産 に対応できない。開発したロボット内蔵工作機械では，ロ ボットを使わないときには機内にコンパクトに収納すると ともに，ワークストッカをスライド移動することで，人が ドアの前に立てる状態に容易に切り替えることができる （図 9)。なお，ワークストッカは安全柵と一体化している ため, ワークストッカをドア前にスライド移動させるだけ で, 安全柵の設置も完了したことになる。これらは，ロボ ットが機外でなく機内にあるために実現できる.

\section{4.おわりに}

本開発では，ロボットシステムを中小企業などの製造現 場に導入する際の課題を解決するため, CNC 旋盤とロボ ットの融合開発を行い, 有用性を確認した上で実用化を行 った。 今後の課題としては, 自動化レベルをさらに引き上 げるため, 機内ロボットとしての高性能化・多機能化, ほ かの構造の工作機械とロボットの融合開発, 融合レベルの さらなる向上などが挙げられる.

\section{参 考 文 献}

1）森村章一：自動化システムの導入容易化を可能にする次世代口 ボットシステム，機械技術， 67, 2 (2019) 11-13.

2）井口憲二：工作機械とロボットが完全融合した次世代ロボット システム「ARMROID」, 機械設計, 69, 5 (2019) 89-92.

3）佐藤新治郎：NC ロボット, 機械と工具 別冊 産業用ロボット ガイドブック，(1981）91-96.

4）辺見信彦, 村田良司, 各務孝：旋削加工用 2 自由度型能動振れ 止め機構の研究, 精密工学会誌, 64, 10 (1998) 1477-1481.

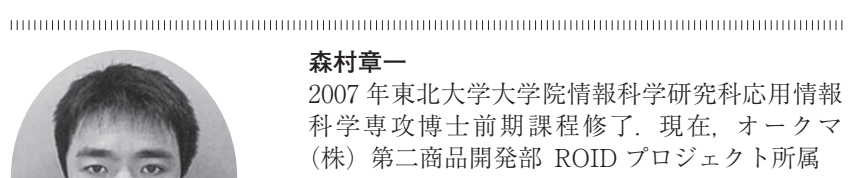

杉浦弘幸

2015 年豊橋技術科学大学大学院工学研究科機械 工学専攻博士前期課程修了. 現在, オークマ (株) 第二商品開発部 ROID プロジェクト所属

井口憲二

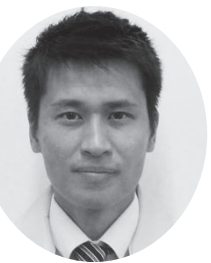

2010 年名古屋工業大学大学院工学研究科機能工 学専攻博士前期課程修了. 現在, オークマ(株) 第二商品開発部 ROID プロジェクト所属

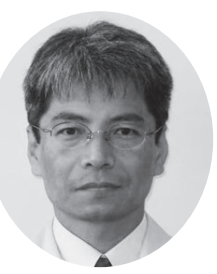

\section{吉村辰浩}

1987 年福井大学工学部産業機械工学科卒業. 現 在，オークマ(株) 第一商品開発部 デザインア ーキテクチヤ開発課 主管技師

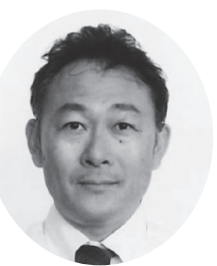

\section{柴田知宏}

1999 年名古屋工業大学大学院工学研究科電気情 報工学専攻博士前期課程修了. 現在, オークマ (株) FA 開発部 次長 